\title{
Feeding habits of billfishes (Carangaria: Istiophoriformes) in the Ecuadorian Pacific Ocean
}

\author{
Peggy Loor-Andrade ${ }^{1,2}$, Jonathan Pincay-Espinoza ${ }^{2}$, Maribel Carrera-Fernández ${ }^{1,2}$ and \\ Rigoberto Rosas-Luis ${ }^{2,3}$
}

The feeding habits of Makaira nigricans, Kajikia audax, Istiophorus platypterus (Istiophoridae), and Xiphias gladius (Xiphiidae) in the southeast Pacific Ocean were examined in Manta and Santa Rosa, Ecuador. This study describes the diets of these billfish species, evaluates dietary differences between species, and assesses seasonal differences in diet. A total of 274 M. nigricans, 321 K. audax, 267 I. platypterus, and 252 X. gladius were collected between February 2014 and April 2015. The scombrid Auxis spp. was the most important prey for M. nigricans, K. audax and I. platypterus, while the squid Dosidicus gigas was the most important prey for $X$. gladius. The results of the ANOSIM confirmed significant differences in feeding habits between the members of the family Istiophoridae and X. gladius. Seasonal differences for I. platypterus also were observed. Billfishes are specialist consumers with a narrow niche breadth ( $B_{\mathrm{a}}:$ M. nigricans and $K$. audax $=0.1, I$. platypterus $=0.05$, and $X$. gladius $=0.04)$.

Keywords: Feeding strategy, Food partitioning, Istiophoridae, Trophic ecology, Xiphiidae.

Los hábitos alimentarios de Makaira nigricans, Kajikia audax, Istiophorus platypterus (Istiophoridae) y Xiphias gladius (Xiphiidae) en el Océano Pacífico sudeste se examinaron en Manta y Santa Rosa, Ecuador. Este estudio describe las dietas de estas especies de peces de pico, evalúa las diferencias de la dieta entre especies y las diferencias estacionales en la dieta. Se obtuvo un total de 274 M. nigricans, 321 K. audax, 267 I. platypterus y 252 X. gladius entre febrero 2014 y abril 2015. El escómbrido Auxis spp. fue la presa más importante para M. nigricans, K. audax y I. platypterus, mientras que el calamar Dosidicus gigas fue la presa más importante para X. gladius. Los resultados de ANOSIM confirmaron diferencias significativas en los hábitos alimentarios entre los miembros de la familia Istiophoridae y $X$. gladius. También se observaron diferencias estacionales para I. platypterus. Los peces de pico son consumidores especialistas con una amplitud de nicho estrecha ( $B_{\mathrm{a}}:$ M. nigricans y $K$. audax $=0.1$, I. platypterus $=0.05$ y $X$.gladius $\left.=0.04\right)$.

Palabras clave: Ecología trófica, Estrategia alimentaria, Istiophoridae, Repartición alimentaria, Xiphiidae.

\section{Introduction}

Commonly known as billfishes, the large fishes of the families Xiphiidae and Istiophoridae are active predators characterized by a protruding upper jaw that extends considerably beyond their lower jaw (Nakamura, 1985). The longline fishery for large pelagic fishes operates year round in Ecuador and billfishes are one of the most important resources for the local artisanal fishery as well (MartínezOrtíz et al., 2015).

The most tropical billfish species is the blue marlin Makaira nigricans Lacépède, 1802, which is commonly found in equatorial waters (Nakamura, 1985). This epipelagic species it is the most oceanic of the istiophorids and is found in coastal waters only where the continental shelf is narrow (Nakamura, 1985; Joseph et al., 1988). The striped marlin Kajikia audax (Philippi, 1887) is an epipelagic predator usually found above the thermocline, although the species migrates to deeper waters at night (Nakamura, 1985; Sippel et al., 2011). The sailfish Istiophorus platypterus (Shaw, 1792) prefers a coastal habitat (Nakamura, 1985) and is usually found within $50 \mathrm{~m}$ of the surface, but undertakes short-duration vertical movements to $150 \mathrm{~m}$ depth (Chiang et al., 2011; Kerstetter et al., 2011). The swordfish Xiphias gladius Linnaeus, 1758 is the sole member of the family Xiphiidae and exhibits the greatest temperature tolerance among billfishes (Nakamura, 1985), performing vertical migrations to more than $900 \mathrm{~m}$ depth (Abascal et al., 2010).

\footnotetext{
${ }^{1}$ Facultad de Ciencias del Mar. Universidad Laica Eloy Alfaro de Manabí. Vía San Mateo S/N. 130802 Manta, Manabí, Ecuador. (PLA) peggysue.loor@gmail.com (corresponding author), (MCF) carreraf.maribel@gmail.com

${ }^{2}$ Departamento Central de Investigación. Universidad Laica Eloy Alfaro de Manabí. Vía San Mateo S/N. 130802 Manta, Manabí, Ecuador. jona.eduar@hotmail.com

${ }^{3}$ Instituto de Ciencias Marinas y Pesquerías, Universidad Veracruzana, Boca del Río, Veracruz, 94290, México.riroluis@yahoo.com.mx
} 
Habitat partitioning is important as it can lead to the consumption of distinct prey in different areas (Shimose et al., 2010); meanwhile, resource partitioning may reduce the competitive pressure between species (Papastamatiou et al., 2006). Prey availability also can be influenced by changes in the primary productivity as well as other biological and physical variables (Olson et al., 2014) that affect the occurrence of billfishes (Shimose et al., 2008; Shimose et al., 2010).

Marine predators provide valuable information about prey abundance and composition (Potier et al., 2007; Olson et al., 2014). Stomach content analyses also facilitate the identification of feeding habits as well as competition or resource partitioning between species that occurs in the same region (Baker, 1966; Vaske et al., 2004; Shimose et al., 2010), ecological aspects that are not commonly considered for billfishes. Traditionally, studies on the feeding habits of billfishes in the Pacific Ocean have focused on a single species (Abitia-Cárdenas et al., 1999; Rosas-Alayola et al., 2002; Shimose et al., 2006; Watanabe et al., 2009; Abitia-Cárdenas et al., 2011; Tsai et al., 2015) or prey group (Rosas-Luis et al., 2016).

Despite their ecological and commercial importance, biological information on these fishes remains scarce, particularly for the Southeast Pacific Ocean. The feeding ecology of billfishes in Ecuador was assessed to: (1) quantify the diet of billfishes, (2) evaluate the possible differences in diet between distinct species and seasons, and (3) describe their feeding strategy.

\section{Materials and methods}

Study area and sample collection. The study area is located off the coast of Manta $\left(0^{\circ} 56^{\prime} 59^{\prime \prime} \mathrm{S}, 80^{\circ} 42^{\prime} 34^{\prime \prime} \mathrm{W}\right)$ and Santa Rosa $\left(02^{\circ} 13^{\prime} 0^{\prime \prime} \mathrm{S}, 80^{\circ} 58^{\prime} 0^{\prime \prime} \mathrm{W}\right)$ (Fig. 1). One of the most important characteristics in this area is the Equatorial Front located between the Galapagos and the Ecuadorian mainland at about $0^{\circ}-3^{\circ}$, that divide the cold nutrient-rich waters of the Humboldt Current, as well as its extension, the South Equatorial Current, from warmer, nutrient-poor surface waters in the north (Wooster, 1969). Front hydrographic conditions determine the formation of convergence and divergence areas in surface levels that promote primary production, zooplankton biomass and fish stocks (Jiménez, 2008). Fishermen place their longline gear approximately 40 to 200 miles from the coastline, mainly overnight. This gear consists of a mainline with 120-300 branch lines, each separated by $40-60 \mathrm{~m}$. Branch lines are 11-34 $\mathrm{m}$ in length and typically hold a J-shaped hook with a curved shank (Martínez-Ortíz et al., 2015).

Billfishes were sampled from the artisanal fishing fleet between February 2014 and April 2015. Samples were collected principally during morning hours, including almost all of the landed specimens. All billfishes were measured (lower jaw-fork length, $L_{\mathrm{LJF}}$ in $\mathrm{cm}$ ) and the stomach contents were stored in a labeled plastic bag and then preserved on ice for transportation to the laboratory. Samples were frozen at $20^{\circ} \mathrm{C}$ until they could be analyzed.

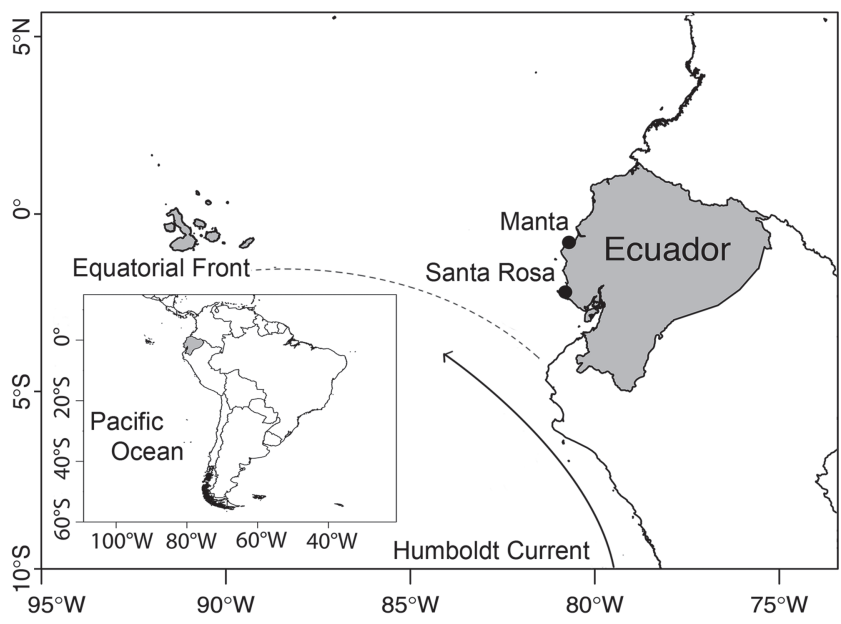

Fig. 1. Map showing the study area. Filled circles represent the sampling localities.

Stomach content analysis. The stomach contents were identified to the lowest taxonomic level, and prey species were counted and weighed to the nearest $0.01 \mathrm{~g}$. Whole fish and cephalopods were identified following Fischer et al. (1995a,1995b), and Jereb, Roper (2010). Other prey items were identified based skeletons or beaks through comparison with the project's fish skeleton collection or published identification guides (Clothier, 1950; Clarke, 1962; Iverson, Pinkas, 1971; Wolff, 1984; Clarke, 1986).

Sample size sufficiency. To evaluate if the sample size was sufficient to describe the full diet, a randomized cumulative prey curve was generated using the "vegan" package (Oksanen et al., 2010) in R (R Development Core Team, 2014) based on the lowest taxonomic level identified for each prey (Preti et al., 2012). The mean species accumulation curve ( \pm 2 standard deviations) was plotted from 500 random permutations of the data. The number of samples is assumed to be sufficient to describe the diet when the curve approaches the asymptote (Hurtubia, 1973). When the asymptote was not evident, a straight line to the last four points was fitted and the slope of the line was compared with a line of slope zero, reaching the asymptote when the lines did not differ significantly (Bizzarro et al., 2007).

Data analysis. To determine the importance of each prey in the diet, the prey-specific index of relative importance (\%PSIRI) (Brown et al., 2012) was used according to the equation: $\% \mathrm{PSIRI}=0.5 \% \mathrm{~F}_{\mathrm{O}}\left(\% \mathrm{P}_{\mathrm{N} i}+\% \mathrm{P}_{\mathrm{wi}}\right)$, where $\% \mathrm{~F}_{\mathrm{O}}$ is the percent frequency of occurrence (the number of stomachs containing prey $i$ divided by the total number of stomachs, $n$ ), and $\% \mathrm{P}_{\mathrm{Ni}}$ and $\% \mathrm{P}_{\mathrm{Wi}}$ are the prey-specific abundances by number or weight, respectively. Prey-specific abundance was calculated with the equation $\% \mathrm{P}_{\mathrm{Ai}}=\sum_{\mathrm{j}=1}^{\mathrm{n}} \% \mathrm{~A}_{\mathrm{ij}} \mathrm{n}_{\mathrm{i}}^{-1}$, where $\% \mathrm{~A}_{\mathrm{ij}}$ is the abundance (by number $\% \mathrm{P}_{\mathrm{Ni}}$ or weight $\% \mathrm{P}_{\mathrm{Wi}}$ ) of prey $i$ in stomach sample $j$ and $n_{i}$ is the number of stomachs containing prey $i$. The \%PSIRI is a modification of the index of relative importance (IRI) (Pinkas et al., 1971). The measure accounts 
for $\% F_{\mathrm{O}}$ redundancies in the $\% \mathrm{IRI}$, and is additive with respect to taxonomic levels. Thus, the \%PSIRI of a family will be equal to the sum of the \%PSIRI of all of the species contained in this taxon (Brown et al., 2012). The stomach content index (SCI) was compared between species using the Kruskal-Wallis test; Dunn's test was applied for post hoc comparisons. This index was calculated as $\mathrm{SCI}=(\mathrm{SCW} \times 100) / \mathrm{PW}$, expressing stomach content weight ( $\mathrm{SCW}$ ) as a ratio of the total weight of all stomachs (PW) for each individual billfish to estimate its stomach fullness (Shimose et al., 2006).

The similarity of the diet between different species and seasons (rainy season $=$ December to May; dry season $=$ June to November) was evaluated using analysis of similarities (ANOSIM). Prey were grouped by family in order to reduce the number of prey categories in the samples with zero values, thus increasing the effectiveness of the multivariate analysis (White et al., 2004; Espinoza et al., 2013; Szczepanski, Bengtson, 2014). Data were permutated 999 times for a distribution to determine the $p$-value of the ANOSIM's $\mathrm{R}$ statistic $(\mathrm{R}=0$ is identical, $\mathrm{R}=-1$ or 1 is most divergent). The SIMPER analysis (Clarke, Warwick, 2001) was used as a post-hoc test to identify the prey taxa responsible for the dissimilarities in the diet of different billfish species.

Levin's standardized measure of niche breadth $\left(B_{\mathrm{a}}\right)$ (Krebs, 1999) was calculated by applying \%PSIRI converted to proportions of the different prey identified. This measure varies from 0 to 1 , where values close to 0 reflect a specialized diet and values close to 1 indicate a generalized diet (Krebs, 1999). Feeding strategy was assessed using the graphical analysis proposed by Amundsen et al. (1996). This procedure, which is a modification of Costello's (1990) graphical method, provides

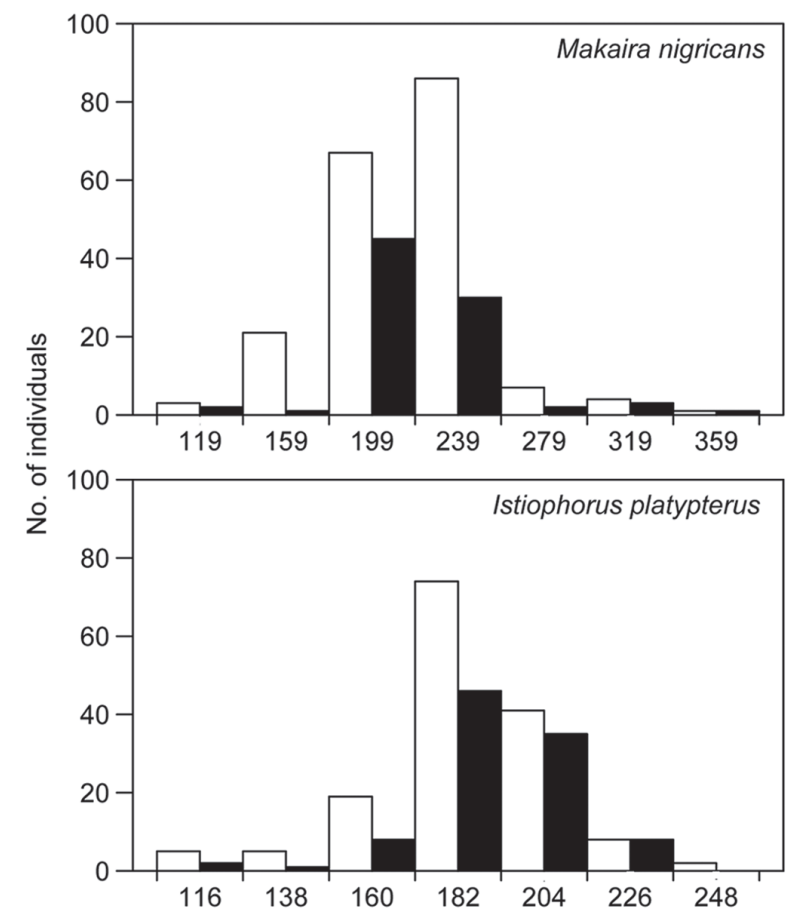

information about prey importance and the predator's feeding strategy by evaluating a two-dimensional plot of prey-specific abundance $(\% P i)$ against $\% F_{0}$, with $\% P i=(\Sigma$ prey $i$ weight $/ \Sigma$ weight of all prey in the stomachs containing prey $i) \times 100$.

\section{Results}

A sample of 273 M. nigricans (119-397 $\mathrm{cm} L_{\mathrm{LJF}}$ ), $321 \mathrm{~K}$. audax $\left(102-265 \mathrm{~cm} L_{\mathrm{LFF}}\right), 267$ I. platypterus $\left(116-272 \mathrm{~cm} L_{\mathrm{LJF}}\right)$, and $252 X$. gladius $\left(100-331 \mathrm{~cm} L_{\mathrm{LJF}}\right)$ were analyzed (Fig. 2). For $M$. nigricans, 84 stomachs contained prey, representing a total of 11 taxa. For $K$. audax, 154 stomachs were found to contain food and a total of 16 taxa were identified. For $I$. platypterus, 100 stomachs containing prey were observed, representing a total of 12 taxa. For $X$. gladius, 108 stomachs were found with food, and a total of 12 taxa were identified. None of the cumulative prey curves for the four billfish species reached the asymptote $(p<0.05)$.

Diet composition. For $M$. nigricans, $K$. audax, and $I$. platypterus, fishes were the most important prey category (90.1, 84.2, and 93.7\% PSIRI, respectively). For these species, the scombrid Auxis spp. made an important contribution to the diet (Tab. 1). For X. gladius, cephalopods were the most important group (89.1\% PSIRI), with the squid Dosidicus gigas (70.3\% PSIRI) being the most representative prey (Tab. 1). The stomach content index (SCI) differed significantly between $M$. nigricans (mean \pm SD: $1.2 \pm 2.0$ ), $K$. audax (mean \pm SD: 0.6 \pm 1.1 ), I. platypterus (mean \pm SD: $1.0 \pm 1.1$ ), and $X$. gladius (mean \pm SD: $0.9 \pm 1.5)(H=23.44, p<0.05)$. K. audax differed significantly in all comparisons (Dunn's test, $p<0.05$ ).
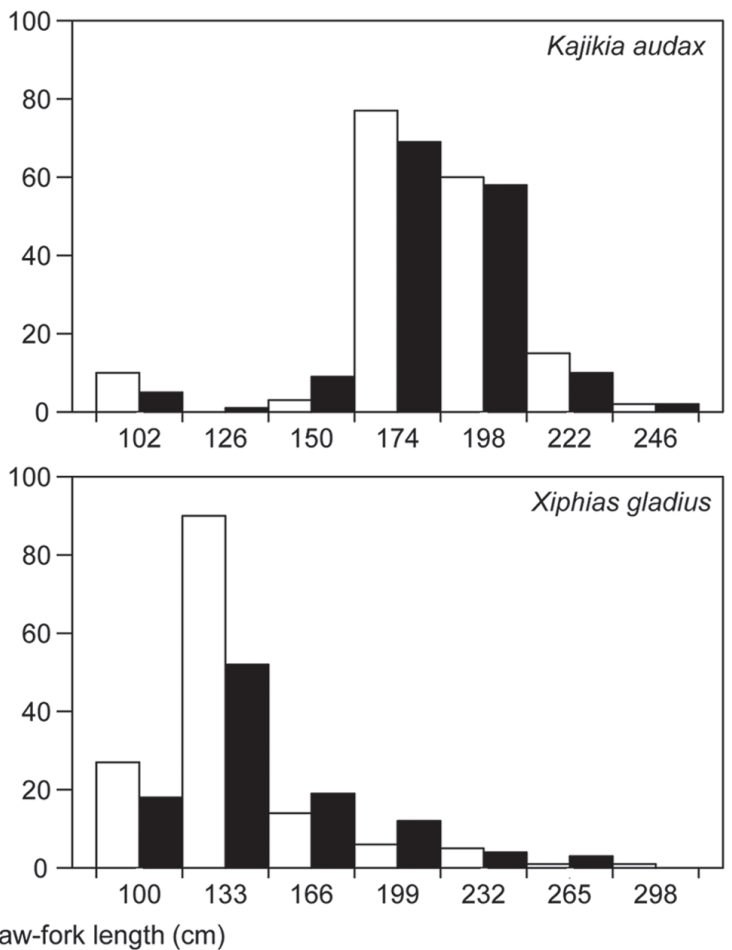

Fig. 2. Combined length-frequency distribution of empty stomachs (white bars) and stomachs containing prey (black bars). 


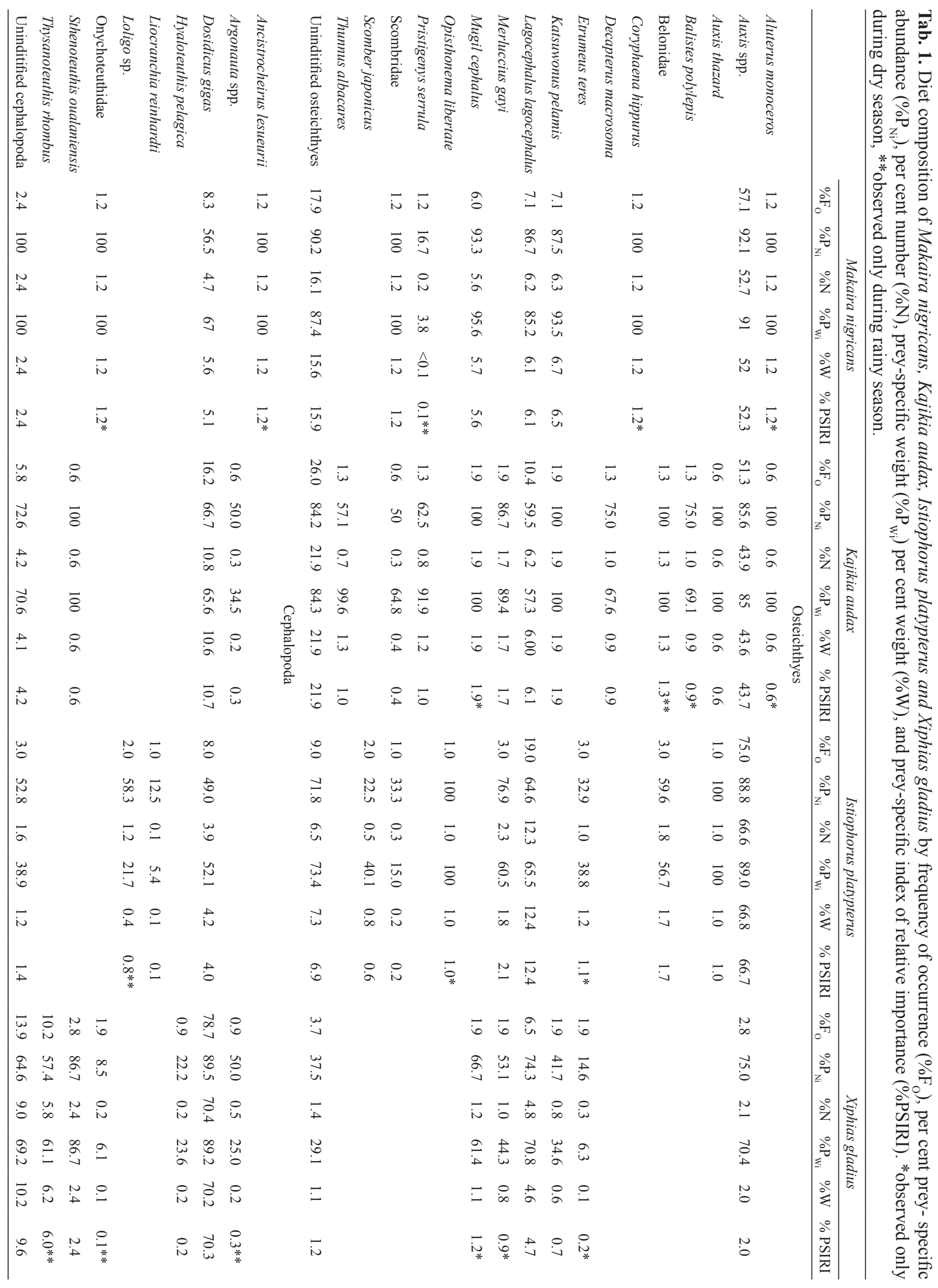


Based on the results of the ANOSIM, there was a significant difference in dietary composition between billfish species $(\mathrm{R}=0.31, p=0.001)$. The SIMPER analysis showed that Auxis spp. and D. gigas were the prey most responsible for differences in the dietary compositions of $X$ gladius and the members of the family Istiophoridae. M. nigricans ingested greater amounts of Auxis spp. than $K$. audax, while I. platypterus consumed more Auxis spp. than M. nigricans and K. audax. Xiphias gladius ingested greater amounts of $D$. gigas in all comparisons.

The results of the ANOSIM showed no differences in the diet among seasons for M. nigricans $\left(\mathrm{n}_{\text {dry }}=42, \mathrm{n}_{\text {rainy }}=\right.$ $42, \mathrm{R}=0, p=0.55), K$. audax $\left(\mathrm{n}_{\text {dry }}=50, \mathrm{n}_{\text {rainy }}=104, \mathrm{R}=0.03\right.$, $p=0.08)$, and $X$. gladius $\left(\mathrm{n}_{\mathrm{dry}}=57, \mathrm{n}_{\text {rainy }}=51, \mathrm{R}=0.03, p=\right.$
$0.11)$ diets; however, significant seasonal differences were observed for I. platypterus $\left(\mathrm{n}_{\mathrm{dry}}=42, \mathrm{n}_{\text {rainy }}=58, \mathrm{R}=0.08\right.$, $p=0.004$ ).

Feeding strategy. The Amundsen graphical analysis suggests that these billfish species are specialist consumers with Auxis spp. being the dominant prey for M. nigricans, K. audax, and I. platypterus, while $D$. gigas is the main prey of $X$. gladius. Several prey are located in the upper left corner of the diagram, suggesting a high between-phenotype contribution to the niche width, with these prey being consumed by a few specialized individuals (Fig. 3). The niche breadths calculated for $M$. nigricans, $K$. audax, I. platypterus, and $X$. gladius were narrow $\left(B_{\mathrm{a}}=0.1,0.1,0.05\right.$, and 0.04 , respectively).

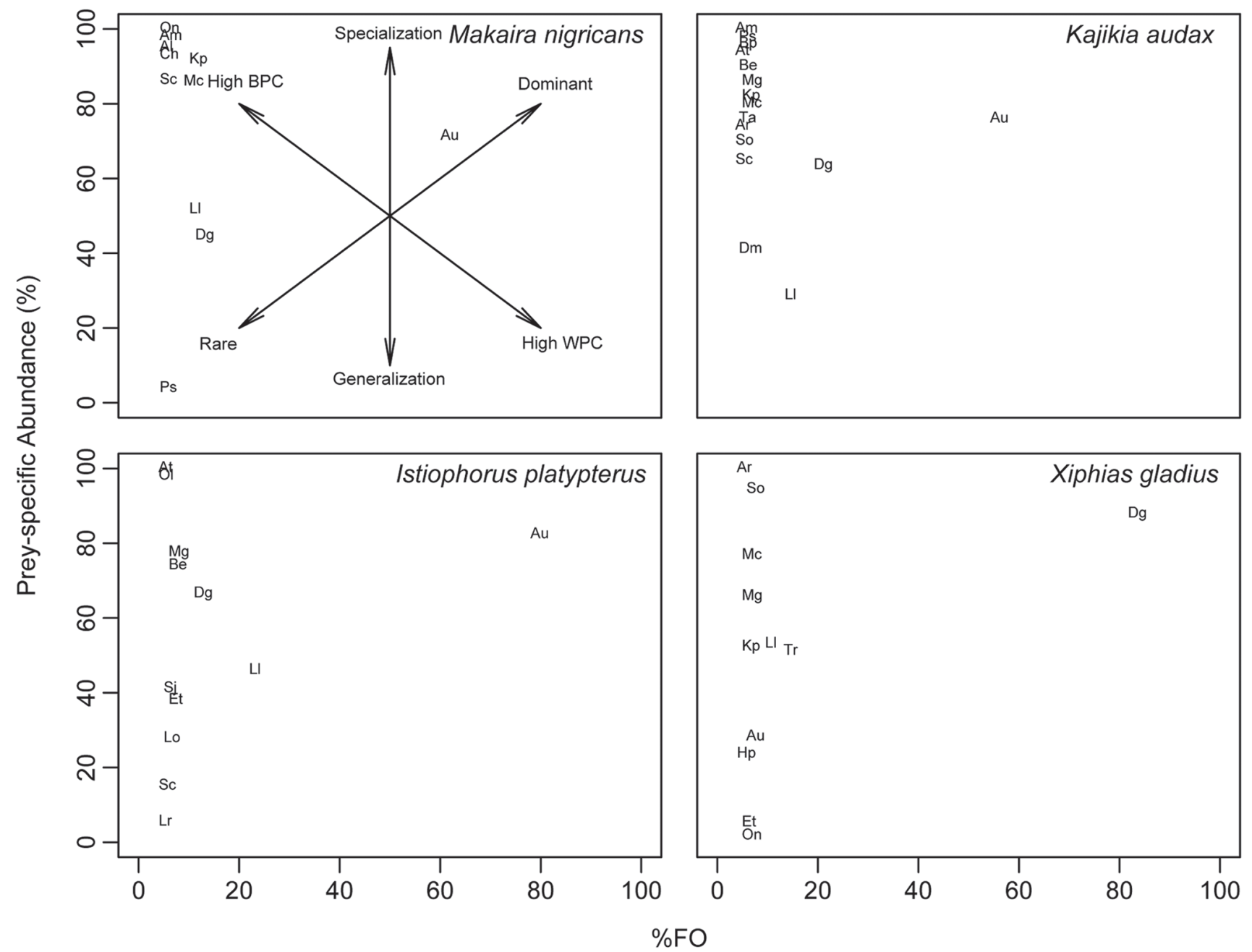

Fig. 3. Prey-specific abundance plotted against frequency of occurrence of prey species. Explanatory axes for foraging patterns are those of Costello (1990) as modified from Amundsen et al. (1996). The two diagonal axes represent the importance of prey (dominant vs. rare) and the contribution to the niche width (high between-phenotype vs. high within-phenotype contribution); the vertical axis defines the predator feeding strategy (specialist vs. generalist). Al, Ancistrocheirus lesueurii; Am, Aluterus monoceros; Ar, Argonauta spp.; At, Auxis thazard; Au, Auxis spp.; Be, Belonidae; Bp, Balistes polylepis; Ch, Coryphaena hippurus; Dg, Dosidicus gigas; Dm, Decapterus macrosoma; Et, Etrumeus teres; Hp, Hyaloteuthis pelagica; Kp, Katsuwonus pelamis, Ll, Lagocephalus lagocephalus; Lo, Loligo sp.; Lr, Liocranchia reinhardti; Mc, Mugil cephalus; $\mathrm{Mg}$, Merluccius gayi; Ol, Opisthonema libertate; On, Onychoteuthidae; Ps, Pristigenys serrula; Sc, Scombridae; Sj, Scomber japonicus; So, Sthenoteuthis oualaniensis; Ta, Thunnus albacares; Tr, Thysanoteuthis rhombus. 


\section{Discussion}

The number of different prey species identified for all billfishes examined in this study was lower than that reported for other areas of the Pacific Ocean (Abitia-Cárdenas et al., 1997; Abitia-Cárdenas et al., 1999; Arizmendi-Rodríguez et al., 2006; Letelier et al., 2009), where these predators include other taxa, like crustaceans, in their diet (Shimose et al., 2006; Watanabe et al., 2009; Abitia-Cárdenas et al., 2011). These billfish species exploit a smaller group of feeding resources in the Ecuadorian Pacific Ocean coinciding with their narrow niche breadth. In the eastern Pacific Ocean, M. nigricans, K. audax, I. platypterus and Tetrapturus angustirostris prey are scarcer near the equator, which may be related to lower productivity (Shimose et al., 2010).

The asymptote was not reached in any of the species accumulation curves despite the large sample size; a number of factors contributed to this, including differential digestion rates, regurgitation of the stomach contents as the result of being caught during fishing (Chase, 2002; Hernández-Aguilar et al., 2013), and the daily periodicity of feeding (Shimose et al., 2006). The low SCI values suggest that these billfishes do not feed actively before dawn or at night in this area. Off the coast of Japan, Shimose et al. (2006) observed that the frequency of empty stomachs among $M$. nigricans tended to be higher in the early morning than at any other time of day, suggesting a daily periodicity in feeding. Furthermore, these low values also may be related to the prey availability in our study area, as prey items varies by area in the Pacific Ocean (Shimose et al., 2010).

Fishes were the main prey group for $M$. nigricans, $K$. audax and I. platypterus in our study area; similar results have been reported by other authors in the North Pacific (AbitiaCárdenas et al., 2002; Shimose et al., 2006), off the coast of Taiwan (Tsai et al., 2015), and in the Ecuadorian Pacific Ocean (Rosas-Luis et al., 2016). Auxis spp. has been reported as an abundant prey in the eastern Pacific Ocean (Olson, Boggs, 1986; Olson et al., 2014); the importance of Auxis spp. for billfishes previously was demonstrated off the coast of Cabo San Lucas, Mexico, for M. nigricans (Abitia-Cárdenas et al., 1999), and off Acapulco, Mexico, for I. platypterus (Hernández-Aguilar et al., 2013). Scombrid fishes, including Auxis thazard and Auxis rochei also have been reported as the most abundant prey group for I. platypterus, M. nigricans, and $K$. audax in the eastern North Pacific Ocean (Shimose et al., 2010).

The most important prey in the billfishes diet varies by geographic location (Shimose et al., 2010). Thus, for $M$. nigricans off the coast of southwestern Japan, Katsuwonus pelamis was important and was consumed mainly during the day (Shimose et al., 2006). Scomber japonicus was the most abundant prey for $K$. audax off the coast of Cabo San Lucas, Mexico (Abitia-Cárdenas et al., 1997), while the Humboldt squid $D$. gigas was the prey most commonly consumed prey by I. platypterus off Mazatlán, Mexico, (ArizmendiRodríguez et al., 2006). Our results demonstrate that Auxis spp. is an important feeding resource in the Ecuadorian Pacific. The Humboldt squid D. gigas was reported previously as a representative prey in the diet of $X$. gladius in the Pacific Ocean (Ibáñez et al., 2004; Castillo et al., 2007; Letelier et al., 2009). This feeding strategy is related to the abundance of this prey species (Nigmatullin et al., 2001) and to the vertical migrations undertaken by both species. During the day, $X$. gladius prey on D. gigas in deep waters (Watanabe et al., 2009), whereas at night they consume the same species on the surface when $D$. gigas migrates there in pursuit of its own prey (Rosas-Luis et al., 2011).

A low trophic overlap was observed between $X$. gladius and the istiophorid fishes, which may be the result of differences in their horizontal distributions. X. gladius is found in deeper waters than members of the family Istiophoridae, allowing it to exploit other areas as well as shallower waters where it is is found at night (Abascal et al., 2010; Abecassis et al., 2012). Furthermore, horizontal movements in this area (Abascal et al., 2010) as well as the importance of D. gigas in the diet may suggest a close prey-predator relationship.

Although istiophorid fishes consume similar diets throughout the Ecuadorian Pacific, there is low trophic overlap between I. platypterus, M. nigricans, Tetrapturus angustirostris and $K$. audax in the eastern North Pacific Ocean where the prey consumed varies by zone and size (Shimose et al., 2010). While stomach content analyses indicate that $M$. nigricans and $K$. audax consume similar diets in the southern Gulf of California, Mexico, stable isotope analyses show significant differences, suggesting niche segregation (TorresRojas et al., 2013).

In the Ecuadorian Pacific Ocean, M. nigricans, K. audax, and $X$. gladius consume distinct prey species during different seasons; however, we did not observe significant differences in our study. In the northern hemisphere off the coast of Cabo San Lucas, Mexico, the number of food components recorded for M. nigricans varies between summer and fall (Abitia-Cárdenas et al., 1999). Off the coast of Mexico, $K$. audax shows seasonal and size-related differences in feeding (Abitia-Cárdenas et al., 2011) wherein cephalopods are the most important prey in the summer, but fishes are the primary prey consumed during spring and fall (AbitiaCárdenas et al., 1997).

The diet of I. platypterus varied seasonally; this contrasts with the results reported for this species off Acapulco, Mexico, where no seasonal differences have been observed in diet (Hernández-Aguilar et al., 2013). This seasonal variation may be influenced by the coastal habitat of this species and the seasonal availability of different prey in the area. In the Ecuadorian Pacific, I. platypterus consumes clupeid fishes like Ophistonema libertate and Etrumeus teres only during the dry season. Ophistonema libertate is abundant in the central region of Ecuador (Patterson, Santos, $1992)$ and E. teres is mainly distributed inshore, coinciding with the coastal habitat preferences of I. platypterus (Nakamura, 1985). Ophistonema libertate catches increase at lower temperatures (Patterson, Santos, 1992); thus, the 
seasonal preference for this prey may be explained by its greater abundance in cooler waters and the opportunistic feeding strategy employed by I. platypterus (Rosas-Alayola et al., 2002; Varghese et al., 2013; Tsai et al., 2015).

In conclusion, these specialist predators consume fewer prey species in the Ecuadorian Pacific than do their counterparts in other regions of the Pacific Ocean. Moreover, resource partitioning occurs between members of the family Istiophoridae and $X$. gladius. As an opportunistic predator, $I$. platypterus varies its diet based on prey availability during different seasons.

\section{Acknowledgments}

To the Universidad Laica Eloy Alfaro de Manabí for their support and the students of the project "Ecología Trófica de los Pelágicos Mayores del Pacífico Ecuatoriano" for their assistance.

\section{References}

Abascal FJ, Mejuto J, Quintans M, Ramos-Cartelle A. Horizontal and vertical movements of swordfish in the Southeast Pacific. ICES J Mar Sci. 2010; 67(3):466-74.

Abecassis M, Dewar H, Hawn D, Polovina J. Modeling swordfish daytime vertical habitat in the North Pacific Ocean from pop-up archival tags. Mar Ecol Prog Ser. 2012; 452(1):219-36.

Abitia-Cárdenas LA, Galván-Magaña F, Cruz-Escalona VH, Peterson MS, Rodríguez-Romero J. Daily food intake of Kajikia audax (Philippi, 1887) off Cabo San Lucas, Gulf of California, Mexico. Lat Am J Aquat Res. 2011; 39(3):449-60.

Abitia-Cárdenas LA, Galván-Magaña F, Gutiérrez-Sánchez FJ, Rodríguez-Romero J, Aguilar-Palomino B, Moehl-Hitz A. Diet of blue marlin Makaira mazara off the coast of Cabo San Lucas, Baja California Sur, Mexico. Fish Res. 1999; 44(1):95-100.

Abitia-Cárdenas LA, Galván-Magaña F, Rodríguez-Romero J. Food habits and energy values of prey of striped marlin, Tetrapturus audax, off the coast of Mexico. Fish B-NOAA. 1997; 95(2):360-68.

Abitia-Cárdenas LA, Muhlia-Melo A, Cruz-Escalona VH, GalvánMagaña F. Trophic dynamics and seasonal energetics of striped marlin Tetrapturus audax in the southern Gulf of California, Mexico. Fish Res. 2002; 57(3):287-95.

Amundsen PA, Gabler HM, Staldvik FJ. A new approach to graphical analysis of feeding strategy from stomach contents data-modification of the Costello (1990) method. J Fish Biol. 1996; 48(4):607-14.

Arizmendi-Rodríguez DI, Abitia-Cárdenas LA, Galván-Magaña F, Trejo-Escamilla I. Food habits of sailfish Istiophorus platypterus off Mazatlán, Sinaloa, México. B Mar Sci. 2006; 79(3):777-91.

Baker AN. Food of marlins from New Zealand waters. Copeia; 1966; 1966(4):818-22.

Bizzarro JJ, Robinson HJ, Rinewalt CS, Ebert DA. Comparative feeding ecology of four sympatric skate species off central California, USA. Environ Biol Fish. 2007; 80(2):197-220.

Brown SC, Bizzarro JJ, Cailliet GM, Ebert DA. Breaking with tradition: redefining measures for diet description with a case study of the Aleutian skate Bathyraja aleutica (Gilbert 1896). Environ Biol Fish. 2012; 95(1):3-20.
Castillo K, Ibáñez CM, González C, Chong J. Diet of swordfish Xiphias gladius Linnaeus, 1758 from different fishing zones off central-Chile during autumn 2004. Rev Biol Mar Oceanogr. 2007; 42(2):149-56.

Chase BC. Differences in diet of Atlantic bluefin tuna (Thunnus thynnus) at five seasonal feeding grounds on the New England continental shelf. Fish B-NOAA. 2002; 100(2):168-80.

Chiang WC, Musyl MK, Sun CL, Chen SY, Chen WY, Liu DC, Su WC, Yeh SZ, Fu SC, Huang TL. Vertical and horizontal movements of sailfish Istiophorus platypterus near Taiwan determined using popup satellite tags. J Exp Mar Biol Ecol. 2011; 397(2):129-35.

Clarke MR. The identification of cephalopod "beaks" and the relationship between beak size and total body weight. Bull $\mathrm{Br}$ Mus (Nat Hist). Zoology. 1962; 8(10):422-80.

Clarke MR. A handbook for the identification of cephalopod beaks. New York: Oxford University Press; 1986.

Clarke KR, Warwick RM. Change in marine communities: an approach to statistical analysis and interpretation. 2nd ed. Plymouth: PRIMER-E Ltd; 2001.

Clothier CR. A key to some southern California fishes based on vertebral characters. State of California Department of Natural Resources. Division of Fish and Game Bureau of Marine Fisheries. Fish Bulletin No. 79; 1950.

Costello MJ. Predator feeding strategy and prey importance: a new graphical analysis. J Fish Biol. 1990; 36(2):261-63.

Espinoza M, Clarke TM, Villalobos-Rojas F, Wehrtmann IS. Diet composition and diel feeding behaviour of the banded guitarfish Zapteryx xyster along the Pacific coast of Costa Rica, Central America. J Fish Biol. 2013; 82(1):286-305.

Fischer W, Krupp F, Schneider W, Sommer C, Carpenter KE, Niem VH, editors. Roma: FAO; 1995a. (Guía FAO para la identificación de especies para los fines de la pesca. Pacífico centro-oriental; vol. 2. Vertebrados-Parte 1).

Fischer W, Krupp F, Schneider W, Sommer C, Carpenter KE, Niem VH, editors. Roma: FAO; 1995b. (Guía FAO para la identificación de especies para los fines de la pesca. Pacífico centro-oriental; vol 3. Vertebrados-Parte 2).

Hernández-Aguilar SB, Abitia-Cárdenas LA, Moreno-Sánchez XG, Arellano-Martínez M, González-Rodríguez E. Trophic spectrum of the sailfish Istiophorus platypterus caught off Acapulco in the southern Mexican Pacific. J Mar Biol Assoc U K. 2013; 93(4):1097-104.

Hurtubia J. Trophic diversity measurement in sympatric predatory species. Ecology. 1973; 54(4):885-90.

Ibáñez CM, González C, Cubillos L. Dieta del pez espada Xiphias gladius Linnaeus, 1758, en aguas oceánicas de Chile central en invierno de 2003. Invest Mar. 2004; 32(2):113-20.

Iverson ILK, Pinkas L. A pictorial guide to beaks of certain eastern Pacific cephalopods. In: Pinkas L, Oliphant MS and Iverson ILK, editors. Food habits of albacore, bluefin tuna, and bonito in California waters. Fish Bulletin 152; 1971. p.83-105.

Jereb P, Roper CFE. Cephalopods of the world. An annotated and illustrated catalogue of cephalopod species known to date. Myopsid and Oegopsid Squids. Rome: FAO; 2010. (FAO species catalogue for fishery purposes; No. 4, vol 2).

Jiménez R. Aspectos Biológicos de El Niño en el Océano Pacífico Ecuatorial. Guayaquil: Universidad de Guayaquil Facultad de Ciencias Naturales-Centro de Biodiversidad CENBIO; 2008.

Joseph J, Klawe W, Murphy P. Tuna and Billfish. Fish without a country. 4th ed. La Jolla: Inter-American Tropical Tuna Commission; 1988. 
Kerstetter DW, Bayse SM, Fenton JL, Graves JE. Sailfish habitat utilization and vertical movements in the southern Gulf of Mexico and Florida straits. Mar Coast Fish. 2011; 3(1):353-65.

Krebs CJ. Ecological Methodology. 2nd ed. Menlo Park: Addison Wesley; 1999.

Letelier S, Meléndez R, Carreño E, Lopez S, Barría P. Alimentación y relaciones tróficas del pez espada (Xiphias gladius Linnaeus, 1758), frente a Chile centro-norte durante 2005. Lat Am J Aquat Res. 2009; 37(1):107-19.

Martínez-Ortíz J, Aires-da-Silva AM, Lennert-Cody CE, Maunder $\mathrm{MN}$. The ecuadorian artisanal fishery for large pelagics: species composition and spatio-temporal dynamics. PLoS ONE. [serial on the Internet]. 2015; 10(8):e0135136. Available from: http://doi:10.1371/journal.pone.0135136

Nakamura I. Billfishes of the world. An annotated and illustrated catalogue of marlins, sailfishes, spearfishes and swordfishes known to date. Rome: FAO; 1985. (FAO fisheries synopsis, 125; vol 5).

Nigmatullin ChM, Nesis KN, Arkhipkin AI. A review of the biology of the jumbo squid Dosidicus gigas (Cephalopoda: Ommastrephidae). Fish Res. 2001; 54(1):9-19.

Oksanen J, Blanchet FG, Friendly M, Kindt R, Legendre P, McGlinn D, O'Hara RB, Simpson GL, Solymos P, Henry M, Stevens MH, Szoecs E, Wagner H. Vegan: community ecology package. R package version 1.17-0; 2010. Available from: http://CRAN.Rproject.org/package0vegan

Olson RJ, Boggs CH. Apex predation by yellowfin tuna (Thunnus albacares): independent estimates from gastric evacuation and stomach contents, bioenergetics, and cesium concentrations. Can J Fish Aquat Sci. 1986; 43(9):1760-75.

Olson RJ, Duffy LM, Kuhnert PM, Galván-Magaña F, BocanegraCastillo N, Alatorre-Ramírez V. Decadal diet shift in yellowfin tuna Thunnus albacares suggests broad-scale food web changes in the eastern tropical Pacific Ocean. Mar Ecol Prog Ser. 2014; 497(1):157-78

Papastamatiou YP, Wetherbee BM, Lowe CG, Crow GL. Distribution and diet of four species of carcharhinid shark in the Hawaiian Islands: evidence for resource partitioning and competitive exclusion. Mar Ecol Prog Ser. 2006; 320(1):239-51.

Patterson KR, Santos M. The thread-herrings Opisthonema spp. off Ecuador: review and population dynamics. Fish Res. 1992; 14(4):273-94

Pinkas L, Oliphant MS, Inverson LK. Food habits of albacore, bluefin tuna and bonito in California waters. State of California: Department of Fish and Game; 1971. (Fish Bulletin; 152).

Potier M, Marsac F, Cherel Y, Lucas V, Sabatié R, Maury O, Ménard F. Forage fauna in the diet of three large pelagic fishes (lancetfish, swordfish and yellowfin tuna) in the western equatorial Indian Ocean. Fish Res. 2007; 83(1):60-72.

Preti A, Soykan CU, Dewar H, Wells RJD, Spear N, Kohin S. Comparative feeding ecology of shortfin mako, blue and thresher sharks in the California Current. Environ Biol Fish. 2012; 95(1):127-46.

R Development Core Team. R: a language and environment for statistical computing [Computer software manual - Internet]. Vienna: R Foundation for Statistical Computing; 2014. Available from: https://www.r- project.org/

Rosas-Alayola J, Hernández-Herrera A, Galván-Magaña F, AbitiaCárdenas LA, Muhlia-Melo AF. Diet composition of sailfish (Istiophorus platypterus) from the southern Gulf of California, Mexico. Fish Res 2002; 57(2):85-195.
Rosas-Luis R, Loor-Andrade P, Carrera-Fernández M, PincayEspinoza JE, Vinces-Ortega C, Chompoy-Salazar L. Cephalopod species in the diet of large pelagic fish (sharks and billfishes) in Ecuadorian waters. Fish Res. 2016; 173:159-68.

Rosas-Luis R, Tafur-Jimenez R, Alegre-Norza AR, CastilloValderrama PR, Cornejo-Urbina RM, Salinas-Zavala CA, Sánchez P. Trophic relationships between the jumbo squid (Dosidicus gigas) and the lightfish (Vinciguerria lucetia) in the Humboldt Current System off Peru. Sci Mar. 2011; 75(3):549-57.

Szczepanski JA, Bengtson DA. Quantitative food habits of the bullnose ray, Myliobatis freminvillii, in Delaware Bay. Environ Biol Fish. 2014; 97(9):981-97.

Shimose T, Shono H, Yokawa K, Saito H, Tachihara K. Food and feeding habits of blue marlin, Makaira nigricans, around Yonaguni Island, southwestern Japan. B Mar Sci. 2006; 79(3):761-75.

Shimose T, Yokawa K, Saito H, Tachihara, K. Seasonal occurrence and feeding habits of black marlin, Istiompax indica, around Yonaguni Island, southwestern Japan. Ichthyol Res. 2008; 55(1):90-94.

Shimose T, Yokawa K, Saito H. Habitat and food partitioning of billfishes (Xiphioidei). J Fish Biol. 2010; 76(10):2418-33.

Sippel T, Holdsworth J, Dennis T, Montgomery J. Investigating behavior and population dynamics of striped marlin (Kajikia audax) from the southwest Pacific Ocean with satellite tags. PLoS ONE. 2011; 6(6):e21087. Available from: http://dx.doi. org/10. 1371/journal.pone.0021087

Torres-Rojas Y, Hernandez-Herrera A, Ortega-García S, Domeier M. Stable isotope differences between blue marlin (Makaira nigricans) and striped marlin (Kajikia audax) in the southern Gulf of California, Mexico. B Mar Sc. 2013; 89(2):421-36.

Tsai CN, Chiang WC, Sun CL, Shao KT, Chen SY, Yeh SZ. Stomach content and stable isotope analysis of sailfish (Istiophorus platypterus) diet in eastern Taiwan waters. Fish Res. 2015; 166:39-46.

Varghese SP, Somvanshi VS, Gulati DK. Ontogenic and seasonal variations in the feeding ecology of Indo-Pacific sailfish, Istiophorus platypterus (Shaw, 1972), of the eastern Arabian Sea. Indian J Geomarine Sci. 2013; 42(5):593-605.

Vaske T, Jr, Vooren CM, Lessa RP. Feeding habits of four species of Istiophoridae (Pisces: Perciformes) from northeastern Brazil. Environ Biol Fish. 2004; 70(3):293-304.

Watanabe H, Kubodera T, Yokawa K. Feeding ecology of the swordfish Xiphias gladius in the subtropical region and transition zone of the western North Pacific. Mar Ecol Prog Ser. 2009; 396(1):111-22.

White WT, Platell ME, Potter IC. Comparisons between the diets of four abundant species of elasmobranchs in a subtropical embayment: implications for resource partitioning. Mar Biol. 2004; 144(3):439-48.

Wolff GA Identification and estimation of size from the beaks of 18 species of cephalopods from the Pacific Ocean. NOAA Technical Report NMFS 17. Springfield: U.S. Department of commerce; 1984.

Wooster WS. Equatorial front between Peru and Galápagos. DeepSea Research Suppl. 1969; 16:407-19.

Submitted November 26, 2016 Accepted August 14, 2017 by Fernando Gibran 